\title{
ENERGY SUSTAINABILITY OF SUPPLY CENTERS FROM THE CODIGESTION OF ORGANIC WASTE
}

\author{
Derovil Antônio dos Santos Filho ${ }^{1}$, Laís Roberta Galdino de Oliveira ${ }^{1}$, Maurício Cabral \\ Penteado ${ }^{2}$, Waldir Nagel Schirmer ${ }^{2, \star}$, Maurício Alves da Motta Sobrinho ${ }^{1}$ and José \\ Fernando Thomé Jucá ${ }^{1}$
}

${ }^{1}$ Universidade Federal de Pernambuco (UFPE), Chemical Engineering, Recife (Pernambuco State), Brazil

${ }^{2}$ Universidade Estadual do Centro-oeste (UNICENTRO), Environmental Engineering, Irati (Paraná State), Brazil
Article Info:
Received:
25 May 2019
Revised:
6 January 2020
Accepted:
8 January 2020
Available online:
10 February 2020
Keywords:
Biogas
Methane
Municipal solid waste
Organic waste valorization
Renewable energy

\begin{abstract}
The present study evaluated the potential for biogas generation from organic waste unfit for consumption collected at the Pernambuco Supply and Logistics Center (CEASA-PE), as well as an estimation of the electric energy production from waste biodigestion generated in this plant. The biogas generation potential used BMP bench-test (biochemical methane potential) biodigesters, in which the biogas production was qualitatively/quantitatively evaluated from CEASA waste codigested with different inocula (bovine ruminal fluid, goat manure and UASB reactor sludge) under mesophilic conditions for 80 days. The laboratory test showed that the waste inoculated with ruminant manures (goat and bovine) presented the lowest net volume of generated biogas compared to the other treatments: 23.2 and $19.2 \mathrm{NmL} . \mathrm{g}_{\mathrm{ds}}{ }^{-1}$. On the other hand, the treatments with sludge and mixture of all the inocula generated the largest biogas volumes: 37.6 and $44 \mathrm{NmL} . \mathrm{g}_{\mathrm{ds}}{ }^{-1}$, respectively. A potential of $359 \mathrm{kWh} \cdot \mathrm{d}^{-1}$ of electric power generation was estimated from the biogas generated at CEASA from the BMP bench assay, as well as from the quantitative and physicochemical parameters of the waste generated in this unit. The results indicate high potential for energy generation in the evaluated CEASA plant, promoting the recovery of these wastes as an alternative and renewable source for sustainable energy production, transforming environmental liabilities into potentially energetic assets of aggregate economic value.
\end{abstract}

\section{INTRODUCTION}

The search for alternative energy sources, preferably cleaner, renewable and sustainable, has become a constant concern on the part of researchers and businesses alike (Schirmer et al., 2016). In this scenario, the use of biomass assumes a relevant role in the gradual replacement of an energy matrix based mainly on the use of fossil fuels (such as petroleum and coal) by a more environmentally friendly matrix. The use of biomass is linked to important factors such as: a) an increase in the global supply of energy; b) the valorization of organic waste, mitigating the social and economic problems associated with its disposal and treatment; c) reduced greenhouse gas emissions, since anthropogenic activities such as handling manure management, wastewater treatment, and landfill management are strongly related to greenhouse gas emission (Abbasi et al., 2012; WEC, 2013). Accompanying this scenario along with the National Policy on Climate Change itself (2009), the Brazilian federal government launched the Na- tional Biofuels Policy (RenovaBio, in Portuguese) in 2017, which aims to (among other commitments) recognize the strategic role of all types of biofuels in the energy matrix of Brazil, both in order to guarantee energy and to minimize greenhouse gases (Brasil, 2017).

Anaerobic digestion is a consolidated biotechnology in recovering organic effluents/waste and comprises the degradation of the organic matter with the consequent production of biogas, a mixture of methane, carbon dioxide, and hydrogen sulfide in percentages which can vary according to the precursor substrate and the process conditions (Cabbai et al., 2013; El-Mashad and Zhang, 2010; Lastella et al., 2002). According to Esposito et al. (2012), sewage sludge, animal manure, food waste, organic solid waste from markets and households, etc. are some of the commonly used substrates in anaerobic digestion processes.

Supply centers represent great potential for generating solid organic waste, and therefore a source of residual bi- 
omass that can be used in energy generation. Considering only the Pernambuco Supply and Logistics Center (CEASA-PE) and based on the 2017 Solid Waste Management Plan, there was a monthly solid waste production of about 1,100 tons; $90 \%$ of which were organic in nature (CEASA-PE, 2017).

The efficiency of the anaerobic digestion process depends on factors such as characteristics of the biodigested waste (volatile solids and nutrients' content), type of biodigestor and the operation parameters $(\mathrm{pH}$, temperature, buffering capacity, etc.) (Alkaya and Demirer, 2011; Schirmer et al., 2014). This efficiency can be improved in terms of the generated biogas yield in the biodigestion process by using a co-substrate (Mata-Alvarez et al., 2000; Mata-Alvarez et al., 2014). Codigestion is the result of anaerobic digestion of two or more substrates with the objective of improving the efficiency of the biodigestion process, maximizing the methane production (Álvarez et al., 2010).

The BMP assay (biochemical methane potential) has been extensively used by researchers as a method to measure the biodegradability of a sample. Low operational cost and a fast response are some of the advantages commonly associated with this method (Barbosa et al., 2018; Labatut et al., 2011; Owen et al., 1979; Schirmer et al., 2014). The literature has reported the anaerobic digestion of the most varied substrates and co-substrates for biogas production: organic fraction of municipal solid wastes inoculated with wastewater sludge and agroindustrial anaerobic sludge from treatment plants (Maciel and Jucá, 2011; Oliveira et al., 2018; Schirmer et al., 2014); organic fraction of municipal solid wastes inoculated with bovine and swine manure (Barbosa et al., 2018); fresh samples of fruits and vegetables wastes (Gunaseelan, 2004), olive mill solid wastes (Rincón et al., 2013), meat-processing wastes (Cavaleiro et al., 2013), among others with high biogas generation potential.

The present work follows the premise of solid waste recovery for energy production, aiming to evaluate the potential of biogas generation from the codigestion of different substrates. The enormous amount of the waste addressed herein generated in Brazil (supply centers, sewage treatment plant sludge and animal waste) should be evaluated as an alternative and renewable source for sustainable energy production.

\subsection{Abbreviations}

BMP: biochemical methane potentia

BRF: bovine ruminal fluid

E: potential of electric power generation

GM: goat manure

LHV: lower heating value of the biogas

OSW: organic solid waste

$\mathrm{P}_{\text {biogs }}$ : daily biogas production

PE: Pernambuco (State of Brazil)

SL: sludge

STP: standard temperature and pressure

TCD: thermal conductivity detector

UASB: upflow anaerobic sludge blanket

VFA: volatile fatty acids
VS: volatile solids content

WWTP: wastewater treatment plant

$\eta_{\text {generator }}$ generator yield

\section{MATERIAL AND METHODS}

\subsection{Substrate and inocula: samples preparation}

Organic solid waste (OSW, adopted as the main substrate) was collected at the Pernambuco Supply and Logistics Center (CEASA-PE) and basically consisted of fruits, greens and vegetables unfit for human consumption. Three inocula were evaluated for OSW: bovine ruminal fluid (BRF) and goat manure (GM), both collected at the Regional Abattoir of Paudalho/PE, and sludge from the UASB reactor (upflow anaerobic sludge blanket) of the "Dancing Days" wastewater treatment plant (WWTP), of Recife (PE) (BRK Ambiental). Once collected, the substrate (OSW) and sludge (SL) were preserved in plastic containers at $4^{\circ} \mathrm{C}$ (CETESB/ANA, 2011), while the animal waste (BRF and $\mathrm{GM}$ ) was kept at room temperature until the samples were processed.

The OSW was fragmented and quarantined in the laboratory according to NBR 10007 (ABNT, 2004). The OSW and inocula were then dried at $105^{\circ} \mathrm{C}$ in a greenhouse until no further mass variation was observed to determine the initial moisture of the waste (WHO, 1978). After drying, the waste was milled in a Wiley mill in order to guarantee homogeneity of the samples and to increase their contact surface area.

\subsection{BMP assays}

The relative volume of inoculum used in the experiment can vary widely, depending on the characteristics of the substrate and the inoculum itself (Angelidaki et al., 2009). In this study, each treatment consisted of 5 grams of OSW (dry and ground) plus inoculum (SL, BRF, GM) until a volume of $50 \mathrm{~mL}$ was reached in each biodigester. In the case of the OSW+GM treatment, distilled water was added to the mixture in sufficient quantity to guarantee sample homogeneity and a moisture content close to $80 \%$ (similar to other mixtures).

Once filled, the biodigesters ( $250 \mathrm{~mL}$ borosilicate vial) were sealed with nylon lids equipped with a manometer (to monitor biogas generation) and valves for the discharge of the biogas generated in the headspace of the vial. In summary, the following treatments were evaluated, all in triplicate: $O S W+S L, O S W+B R F, O S W+G M, O S W+S L+B R F+G M$ and blanks (biodigesters containing only the inocula, whose biogas production was subtracted from the production of the mixtures). The anaerobiosis of the medium was guaranteed by recirculating $\mathrm{N}_{2}$ (inert gas) for 1 minute in the headspace of each flask (Mshandete et al., 2004; Schirmer et al., 2014). The biodigesters were kept under mesophilic conditions $\left(37^{\circ} \mathrm{C}\right)$ for 80 days. The following physicochemical parameters of the treatments were determined before and after the biodigestion period: moisture, volatile solids - VS (NBR 13999; ABNT, 2003) and pH, according to the Standard Methods for the Examination of Water and Wastewater (APHA, 2005). 


\subsection{Monitoring and characterization of biogas}

The biogas generated in the biodigesters was monitored daily from the manometer pressure readings of each flask, as well as atmospheric pressure and incubation temperature. The pressure values were converted to the biogas volume in standard temperature and pressure (STP) (Labatut et al., 2011). The concentrations of the main components of the biogas (methane - $\mathrm{CH}_{4}$, and carbon dioxide $\mathrm{CO}_{2}$ ) were determined in a gas chromatograph (Appa Gold) with a thermal conductivity detector (TCD) and Porapak $\mathrm{N}$ packed column (80/100 mesh; 3.0 m length). The temperatures of the injector, detector and furnace were $140^{\circ} \mathrm{C}$, $150^{\circ} \mathrm{C}$ and $60^{\circ} \mathrm{C}$, respectively, with a hydrogen flow of 30 $\mathrm{mL} \cdot \mathrm{min}^{-1}$. The biogas samples were collected at the end of the test (80th day) in a $1 \mathrm{~mL}$ syringe and injected into the chromatograph for analysis.

\subsection{Estimation of the electric energy production from the anaerobic biodigestion of CEASA waste}

The potential for generating electric energy at the CEASA-PE plant (Recife) was estimated from the best biogas production conditions and final methane concentration during the BMP assays. Table 1 shows the quantity and characteristics of waste generated at CEASA.

Kunz and Oliveira (2006) reported a method for calculating the daily production of biogas relating the biochemical methane potential (BMP) to the concentration of volatile solids in the waste and its daily flow, according to Equation 1:

$P_{\text {biogas }}=B M P * C_{V S}^{*} Q_{\text {dig }}$

In which:

$\mathrm{P}_{\text {biogas }}=$ daily biogas production $\left(\mathrm{m}^{3} \cdot \mathrm{d}^{-1}\right)$

BMP = potential for biogas generation $\left(\mathrm{m}^{3} \cdot \mathrm{kg}_{\mathrm{vs}}{ }^{-1}\right.$ or $\left.^{3} \cdot \mathrm{kg}_{\mathrm{ds}}{ }^{-1}\right)$

CVS $=$ volatile solids $\left(\mathrm{kg}_{\mathrm{vs}} \cdot \mathrm{m}^{-3}\right)$

Qdig = daily waste generation $\left(\mathrm{m}^{3} \cdot \mathrm{d}^{-1}\right)$

It is possible to determine the potential of electric energy generation from the daily biogas production data, meaning the amount of energy which can be obtained by converting the biogas to electric energy using a gas generator.

According to Coelho et al. (2016), the potential electric energy generation can be determined through the daily biogas production (considering the efficiency of the biodigestor), its lower calorific value, as well as the yield of the generator that will be used (Equation 2).

TABLE 1: Quantitative and physicochemical waste parameters from CEASA (PE).

\begin{tabular}{|c|c|}
\hline \multicolumn{2}{|l|}{ Parameter } \\
\hline Daily waste generation* ton. $\left.^{-1}{ }^{-1}\right)$ & 36.7 \\
\hline Volatile solids $\left(\mathrm{kg}_{\mathrm{vs}} \cdot \mathrm{m}^{-3}\right)$ & 162.5 \\
\hline Total solids $\left(\mathrm{kg}_{\mathrm{ds}} \cdot \mathrm{m}^{-3}\right)$ & 215 \\
\hline Moisture (\%) & 78,5 \\
\hline Potential for biogas generation ${ }^{\star \star}\left(\mathrm{NmL} \cdot \mathrm{g}_{\mathrm{vs}}{ }^{-1}\right.$ or NmL.g. $\left.\mathrm{ds}^{-1}\right)$ & 27.1 or 20.5 \\
\hline $\begin{array}{l}\text { * CEASA (2017) } \\
\text { ** Determined from the BMP assay }\end{array}$ & \\
\hline
\end{tabular}

$E=P_{\text {biogas }}{ }^{*} L H V_{\text {biogas }} * \eta_{\text {generator }}$

In which:

$E=$ potential of electric power generation $\left(k W h . d^{-1}\right)$

$\mathrm{P}_{\text {biogas }}=$ daily biogas production $\left(\mathrm{Nm}^{3} . \mathrm{d}^{-1}\right)$

$\mathrm{LHV}_{\text {biogas }}=$ lower heating value of the biogas $\left(\mathrm{kWh} . \mathrm{Nm}^{-3}\right)$, obtained from NBR 15213 (ABNT, 2008)

$\eta_{\text {generator }}=$ generator yield (\%); efficiency of electricity generation from biogas of approximately 40\% (Scarlat, Dallemand and Fahl, 2018; Van Foreest, 2012).

\section{RESULTS AND DISCUSSION}

\subsection{Evaluation of physicochemical waste parame- ters}

Table 2 presents the mean values of the parameters moisture, $\mathrm{pH}$ and volatile solids of the evaluated treatments before and after the biodigestion period.

The moisture and $\mathrm{pH}$ of the waste mass are among the main parameters related to biogas generation. The literature has reported several ranges of moisture content as being more appropriate to biodegrading solid waste, depending on the conditions under which such degradation occurs (Eck, 2000). USEPA (1991) reports that high moisture contents $(60-90 \%)$ tend to favor the biogas generation rate. Table 2 shows that all treatments started from values close to $80 \%$ (in the start-up of the biodigesters); the small increase in moisture content observed at the end of the process is most likely due to the conversion of biomass (solid) to gas during the waste biodigestion.

Concerning $\mathrm{pH}$, literature reports a wide range of values as favorable for methane generation: between 6.7 and 7.5 (Deublein and Steinhauser, 2008), 5.5 and 8.5 (with an optimum range at 7.0-8.0) (Al Seadi et al., 2008), and so on. In a typical anaerobic digestion, the formation of volatile fatty acids (VFA - intermediate compounds such as acetate, propianate, butyrate) in the acidogenesis stage and the high carbon dioxide concentration observed in the biodigestion process determine a decrease in the $\mathrm{pH}$ of the medium (Al Seadi et al., 2008; O'Leary and Tchobanoglous, 2002). An increase in $\mathrm{pH}$ occurs in the subsequent biodigestion stages, and the system tends to return to neutrality, which in fact was observed in the final $\mathrm{pH}$ values reported in Table 2 after 80 days of incubation and for all the treatments, regardless the mixture OSW/inoculum. Substrates with a high proportion of animal manure (as in the treatment OSW+GM) have a greater accumulation tendency of these acids (VFA) in the mixture, implying in reduced $\mathrm{pH}$ values of the system (Al Seadi et al., 2008). However, this higher accumulation of VFA in the medium does not seem to have compromised the biogas production (with an inhibition properly said) but only slow down the return of medium $\mathrm{pH}$ to neutrality (at least within the evaluated period - 80 days), which may justify the slightly lower value (6.2) for the OSW+GM mixture (compared to the other mixtures).

All initial values of VS reported in Table 2 are higher than $60 \%$, indicating a high biogas generation potential from the evaluated substrates. However, a low conversion percentage was observed in all treatments (16.4; 5.2; 16.5 and $20.1 \%$ for OSW+SL, OSW+BRF, OSW+GM e 
TABLE 2: Physicochemical parameters of waste stabilization.

\begin{tabular}{|c|c|c|c|c|c|c|c|c|}
\hline \multirow{3}{*}{ Parameter } & \multicolumn{8}{|c|}{ Treatment } \\
\hline & \multicolumn{2}{|c|}{ OSW + SL } & \multicolumn{2}{|c|}{ OSW + BRF } & \multicolumn{2}{|c|}{ OSW + GM } & \multicolumn{2}{|c|}{$\mathrm{OSW}+\mathrm{SL}+\mathrm{BRF}+\mathrm{GM}$} \\
\hline & Initial & Final & Initial & Final & Initial & Final & Initial & Final \\
\hline Moisture (\%) & 84.4 & 85.7 & 88.0 & 89.0 & 79.2 & 83.0 & 78.5 & 79.2 \\
\hline $\mathrm{pH}$ & 7.2 & 7.6 & 7.1 & 7.5 & 7.7 & 6.2 & 7.5 & 8.2 \\
\hline VS (\%) & 67.8 & 56.7 & 63.4 & 60.1 & 78.9 & 65.9 & 75.6 & 60.4 \\
\hline \multicolumn{9}{|c|}{$\begin{array}{l}\text { OSW: organic solid waste } \\
\text { SL: sludge } \\
\text { GM: goat manure } \\
\text { BRF: bovine ruminal fluid }\end{array}$} \\
\hline
\end{tabular}

OSW+SL+BRF+GM, respectively), indicating a high residual potential of degradation, even after the 80 days of incubation. Thus, the final VS values observed were still high. According to Decottignies et al. (2005), a waste can be considered stable (degraded) when it presents VS content to the order of 10 to $17.4 \%$. The VS reduction values reported in Table 2 are much lower, for example, than those found by Schirmer et al. (2014), which observed reductions of 43.2 and $47.4 \%$ for fresh and 1-year-old wastes (both inoculated with WWTP sludge), respectively, in the same digestion period (80 days) in BMP assays under mesophilic conditions and a substrate/inoculum ratio close to that used in the present study. Thus, although the volatile solids content is among the main parameters to evaluate the waste biodegradability, some substrates can show a very slow degradation kinetics under anaerobic conditions. For these cases, the literature has reported several methods for the pretreatment of these residues (physical, chemical, thermophysical, thermochemical, biological) in order to enhance the biogas production. However, none of these techniques were employed in the present study so that we could analyze the viability of biogas generation from the "in natura" use of all evaluated substrates and inocula, allowing a better comparison between the biogas generation potential of each one.

\subsection{Biogas monitoring}

\subsubsection{Biogas generation}

The OSW inoculated with ruminant wastes (GM and BRF) presented the lowest generated net biogas volume compared to the other treatments: 116 and $96 \mathrm{NmL}$, or 23.2 and $19.2 \mathrm{NmL}_{\mathrm{ds}}{ }^{-1}$ (volume of biogas per dried solid mass) for OSW+GM and OSW+BRF, respectively. Regarding to the manure treatment (GM), a low biogas production can be attributed to the large amount of ammonia, which constitutes an important anaerobic digestion process inhibiting agent present in animal waste (Yenigün and Demirel, 2013), and to the high lignin content, also present in the animal manure (a lignocellulosic substrate) and that affects negatively the biodigestion process. It is known that the presence of inhibitory agents (ammonia, sulfides, heavy metals, etc.) is strongly related to low biogas production. In turn, the rumen constitutes a complex ecosystem of microorganisms that inhabit the animal's gastrointestinal system (fungi, protozoa, bacteria, etc.) (Mackie, 2002) and the animal's own diet has a direct effect (qualitative and quantitative) in ruminal microbiology (Wlodarski et al., 2017). A feed based on silage, pasture, feed, etc. can influence biogas generation, since many of the heavy metals and sulfur compounds come from feed and/or chemical supplements administered to the animal (Barbosa et al., 2018). However, no microbiological analysis of rumen or inhibitor compounds was performed in the present study in order to justify a greater or lesser generation of biogas from this inoculum.

On the other hand, treatments with sludge (SL) and mixture of all inocula (SL BRF+GM) generated the largest biogas volumes: $188 \mathrm{NmL}$ and $220 \mathrm{NmL}$ (37.6 and $44 \mathrm{NmL} . \mathrm{g}_{\mathrm{ds}}$. 1, or $23.1 \mathrm{NmL} . \mathrm{g}_{\mathrm{vs}}{ }^{-1}$ and $27.1 \mathrm{NmL} . \mathrm{g}_{\mathrm{vs}}{ }^{-1}$, respectively) for the $\mathrm{OSW}+\mathrm{SL}$ and $\mathrm{OSW}+\mathrm{SL}+\mathrm{BRF}+\mathrm{GM}$ treatments, respectively. The higher biogas volume observed in the treatment with all mixed inoculants is most likely due to the synergy between the wastes and the microorganisms present in the medium promoted by the codigestion of several substrates and also the dilution of inhibitory agents.

Figure 1 presents the daily biogas generation rate $\left(\mathrm{NmL}^{-1}\right)$ of each evaluated treatment. Biogas generation from their respective blanks has already been subtracted from these results.

The rate of biogas production followed the curve pattern reported by Al Seadi et al. (2008) for batch tests. The biogas peaks observed in the first days of experiment are due to the hydrolysis of easily degradable compounds; in addition, the high inoculum/substrate ratio adopted in all treatments also contributed to this behavior (Parawira et al., 2004). Most of the generated biogas occurred within the first 30 days of incubation in all evaluated treatments. In this aspect, OSW treatment with all inocula was shown to be the most uniform in terms of daily generation, with a more distributed generation throughout the period of the sample digestion compared to the other treatments.

It's important to highlight that the comparison of biodegradability curves found in the literature may be a hard task (Angelidaki et al., 2009), once the specific conditions of each experiment (temperature, time of incubation, pretreatment of the substrates, $\mathrm{pH}$, moisture, nutrients, etc.) as well as the kind of substrates can vary a lot. Besides the biodegradability curves, biogas generation values found in the literature can vary greatly, even for similar digestion conditions and substrates. In the present study, the biogas volumes generated for the best mixtures (OSW+SL and $\mathrm{OSW}+\mathrm{SL}+\mathrm{BRF}+\mathrm{GM}$ ) were relatively low. As already above-mentioned, we didn't employ any technique to pre- 


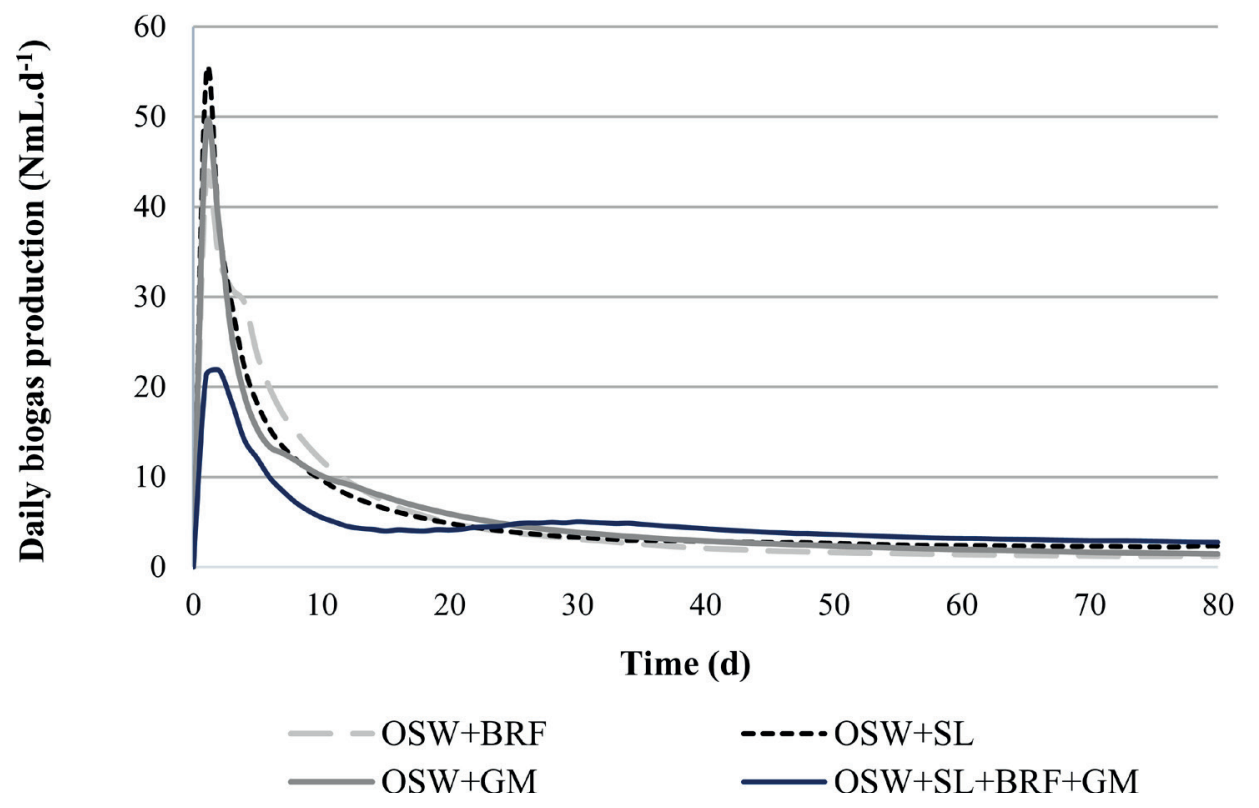

FIGURE 1: Daily biogas generation rate of the treatments evaluated in the biodigestion period.

treat these residues so that we could compare the biogas generation potential without any modification of their original features. Besides, several reasons can also be related to a "lower" biogas generation and that were not evaluated here, such as the concentration of nutrients in substrates and inocula, microrganisms population, lignocellulosic content and the presence of inhibitor or toxic agents in the biodigesters (as ammonia, heavy metals, sulphide, etc.) that, even in a very small concentration, may interfere with the quality of biodigestion.

\subsubsection{Methane and carbon dioxide concentrations}

Table 3 presents the biogas characterization at the end of the experiment for the four evaluated treatments.

Biogas typically presents methane $\left(\mathrm{CH}_{4}\right)$ concentrations in a range between $55-70 \%$, and carbon dioxide $\left(\mathrm{CO}_{2}\right)$ in the range of $30-45 \%$ (Deublein and Steinhauser, 2008). However, Rasi et al. (2011) reported that biogas composition can vary greatly depending on the precursor substrates and the biodigestion process conditions (humidity, temperature, $\mathrm{pH}$, etc.). This composition tends to vary, even during biodigestion, depending on the waste degradation phase (acidogenesis, methanogenesis, etc.). For example, in investigating the anaerobic biodegradation of potato residues alone and codigested with beet leaves inoculated with anaerobic digester sludge in different proportions, Parawira et al. (2004) obtained a very distinct behavior in terms of final methane composition, with concentrations varying between $\cong 10$ and $\cong 70 \%$.

Table 3 shows that the OSW+SL and OSW+BRF+SL+GM treatments were the only ones that presented a final methane concentration within the 'theoretical range' (55 - 70\%). As observed in biogas generation, OSW inoculated with ruminant manure (GM and BRF) presented the lowest final levels of methane in the biogas. In a study on anaerobic biodigestion of manure produced by five animal species (layer poultry, cattle, goats, broiler chickens and pigs), Or- rico Jr. et al. (2011) also generally found a low observed methane potential (in L. $\mathrm{kg}^{-1}$ of volatile solids of manure) for ruminant manure (bovine and goat).

Animal manure is associated with a very low methane yield (Al Seadi et al., 2008). Besides, some of the previously mentioned factors such as the presence of inhibitory agents in animal feed, ammonia present in goat manure, sulfur compounds formed during biodigestion, etc., among other important process parameters such as medium buffering capacity and organic load control (to avoid system overload) have direct interference with the 'success' of the methanogenic biodigestion phase. The combination of some of these parameters, to a greater or lesser extent, could justify the $0.0 \%$ methane found in the biodigestion of the OSW + GM treatment.

Thus, the control of these parameters can be fundamental in cases of mixtures (codigestion) with specific substrates, such as animal waste. In this context, the literature suggests some measures of process control, and consequently optimizing the biomethanization of these wastes (Pearse et al., 2018). Although cheaper and simple technology, batch biodigesters (like BMPs, used in the present study) have lower yields in terms of biogas generation (Vandevivere et al., 2002; Ward et al., 2008), as well as not allowing operator interference in eventual corrections of process parameters. Biomethanization of organic waste comprises a series of steps (hydrolysis, acidification, etc.) for methane formation. In single-stage systems, all these reactions perform in a single digester, whereas this sequence of biochemical reactions occurs in at least two reactors in systems of two or more phases (Vandevivere et al., 2002). The biodigestion phase separation (hydrolysis and acidogenesis of acetogenesis and methanogenesis) is an important step in optimizing the biodigestion process (Ward et al., 2008), and could be applied to similar studies to that proposed herein in order to allow greater monitoring and control over the process steps, and thus a larger gen- 
TABLE 3: Average concentrations of $\mathrm{CH}_{4}$ and $\mathrm{CO}_{2}$ at the end of the experiment.

\begin{tabular}{l|c|c}
\hline Treatment & [ $\left.\mathbf{C H}_{4}\right]$, in \% & [ $\mathbf{C O}_{2}$ ], in \% \\
\hline OSW + BRF & 41.2 & 58.8 \\
\hline OSW + SL & 55.7 & 44.3 \\
\hline OSW + GM & 0.0 & 100.0 \\
\hdashline OSW + BRF + SL + GM & 59.8 & 40.2 \\
\hline
\end{tabular}

eration of biogas/methane.

\subsection{Estimation of electric energy production from the waste biodigestion from CEASA}

The estimated biogas production was $161 \mathrm{~m}^{3} . \mathrm{d}-1$. Considering NBR 15213 (ABNT, 2008) and the methane content in the biogas experimentally determined for the best condition of the BMP assay ( $\cong 60 \%$, in the OSW+BRF+SL+GM treatment), LHV determined for the biogas was $4,796 \mathrm{kcal}$. $\mathrm{Nm}^{-3}$ (or $5.6 \mathrm{kWh} . \mathrm{Nm}^{-3}$ ). According to the scenario adopted in the present study, the OSW generated at CEASA (PE) has potential for generating $359 \mathrm{kWh} . \mathrm{d}^{-1}$ of electricity from the biogas generated in this plant. Therefore, the application of a biodigestor for energy use in a plant with large organic waste generation (as CEASA) constitutes a great alternative in relation to the reducing the expenses of this unit with electric energy.

However, in practice, a technical and financial feasibility study is needed in order to obtain more project details, such as the payback time of implementing the proposal, for example. In addition, one of the main points to be addressed in a feasibility study is biogas purification technology. An analysis of the gas concentrations which compose the biogas is essential for the intent of energy utilization (defining the biogas purification technology to be implemented). In addition to methane (the main energy component), biogas is composed of carbon dioxide, water vapor (substances that reduce burning efficiency), and hydrogen sulphide, a highly corrosive compound that implies a reduction in generator life. Two technologies commonly used in the biogas purification stage are water scrubbing and adsorption with activated carbon (Bauer et al., 2013), which could be adopted in this study (CEASA) to obtain a biogas with better quality in terms of methane and being free from sulphur compounds.

\section{CONCLUSIONS}

There were quite different behaviors in terms of biogas generation in the biodigestion evaluation stage of the OSW codigested with bovine ruminal fluid, goat manure and UASB sludge under mesophilic conditions. Wastes only codigested with ruminant manure (goat and bovine) had significantly lower net volumes of biogas (up to $56 \%$ lower) compared to the other treatments. Similarly, methane concentrations determined at the end of the biodigestion period were greater than $55 \%$ for treatments with sludge and all mixed inocula, remaining at $41 \%$ for treatment with bovine rumen or even $0.0 \%$ for treatment using only the goat manure as inoculum. Factors related to the presence of inhibitors or a higher lignin content in animal inocula pres- ent in feed and manure may be related to the lower biogas generations. On the other hand, the greater biogas volume observed in the treatment with all mixed inoculants is most likely due to the synergy between the wastes (carbon content, nutrients, etc.) and the microorganisms present in the medium promoted by the codigestion of these substrates, as well as to the dilution of these inhibitory agents.

About the electric energy production from the biogas volume generated on the scenario evaluated, a potential of electric power generation of 359 kWh.d-1 (or 10.76 MWh. $\mathrm{m}^{-1}$ ) was determined from the biogas generated at the evaluated CEASA plant. It should be remembered that this study is a theoretical estimate of the potential for biogas generation and electric energy obtained therefrom, and that ideal conditions for reactor operation are adopted in bench-scale tests, which may imply higher values than those obtained in practice.

\section{ACKNOWLEDGEMENTS}

The authors acknowledge the Fundação de Amparo à Ciência e Tecnologia de Pernambuco (FACEPE) for the financial support, and the Centro de Abastecimento Logístico (CEASA/PE) for supplying the wastes used in the study.

\section{REFERENCES}

Abbasi T, Tauseef SM, Abbasi SA (2012) Anaerobic digestion for global warming control and energy generation - An overview. Renewable and Sustainable Energy Reviews, 16:3228-3242.

ABNT - Associação Brasileira de Normas Técnicas (2003) NBR 13.999:2003, Papel, cartão, pastas celulósicas e madeira - Determinação do resíduo (cinza) após a incineração a $525^{\circ} \mathrm{C}$. $4 p$. [in Portuguese]

ABNT - Associação Brasileira De Normas Técnicas (2004) NBR 10007:2004, Amostragem de resíduos sólidos. 21p. [in Portuguese]

ABNT - Associação Brasileira de Normas Técnicas (2008) NBR 15213:2008, Gás natural e outros combustíveis gasosos - Cálculo do poder calorífico, densidade absoluta, densidade relativa e índice de Wobbe a partir da composição. 44 p. [in Portuguese]

Al Seadi T, Rutz D, Prassl H, Köttner M, Finsterwalder T, Volk S, Janssen R (2008) Biogas Handbook. 1.ed. Denmark: University of Southern Denmark Esbjerg. 125p.

Alkaya E, Demirer GN (2011) Anaerobic mesophilic co-digestion of sugar-beet processing wastewater and beet-pulp in batch reactors. Renewable Energy, 36:971-975

Álvarez JA, Otero L, Lema JM (2010) A methodology for optimising feed composition for anaerobic co-digestion of agro-industrial wastes. Bioresource Technology, 101:1153-1158.

Angelidaki I, Alves M, Bolzonella D, Borzacconi L, Campos JL, Guwy AJ, Kalyuzhnyi S, Jenicek P, Van Lier JB (2009) Defining the biomethane potential (BMP) of solid organic wastes and energy crops: a proposed protocol for batch assays. Water Science \& Technology, 59:927-934.

APHA - Standard Methods for the Examination of Water and Wastewater, American Public Health Association, American Water Works Association (2005) 21.ed. Washington: Water Environmental Federation. $541 \mathrm{p}$.

Barbosa FJL, Cabral AR, Capanema MA, Schirmer WN (2018) Biogas generation potential of anaerobic co-digestion of municipal solid wastes and livestock manures. Journal of Solid Waste Technology and Management, 44:248-258.

Bauer F, Hulteberg C, Persson T, Tamm D. (2013) SGC - Svenskt Gastekniskt Center. Rapport 2013:270, Biogas upgrading - Review of commercial technologies. 82p.

Brasil - Presidência da República. Law 13.576 (2017) Dispõe sobre a Política Nacional de Biocombustíveis (RenovaBio) e dá outras providências. Available at <http://www.planalto.gov.br/ccivil_03/_ ato2015-2018/2017/lei/L13576.htm> Accessed: 17 Ago 2018. [in Portuguese] 
Cabbai V, Ballico M, Aneggi E, Goi D (2013) BMP tests of source selected OFMSW to evaluate anaerobic codigestion with sewage sludge. Waste Management, 33:1626-1632.

Cavaleiro AJ, Ferreira T, Pereira F, Tommaso G, Alves MM (2013) Biochemical methane potential of raw and pre-treated meat-processing wastes. Bioresource Technology, 129:519-525.

CEASA-PE - Centro de Abastecimento e Logística de Pernambuco (2017) Plano de Gerenciamento de Resíduos Sólidos (PGRS). Recife: CEASA-PE, 57p. [in Portuguese]

CETESB/ANA - Companhia Ambiental do Estado de São Paulo / Agência Nacional de Águas (2011) Guia nacional de coleta e preservação de amostras - Água, sedimento, comunidades aquáticas e efluentes líquidos. 2.ed. São Paulo: CETESB; Brasília: ANA, 326p. [in Portuguese]

Coelho WLV, Da Silva FS, Dallacort R, Carneiro PAV (2016) Análise do potencial de geração de energia elétrica a partir dos resíduos do setor sucroenergético no Estado de Mato Grosso em diferentes cenários produtivos. Revista Brasileira de Energias Renováveis, 05:332-351. [in Portuguese]

Decottignies V, Galtier L, Lefebvre X, Villerio T (2005) Comparison of analytical methods to determine the stability of municipal solid waste and related wastes. In: Proceedings Sardinia, Tenth International Waste Management and Landfill Symposium, Cagliari, Italy.

Deublein D, Steinhauser A (2008) Biogas from waste and renewable resources. 2.ed. Weinheim: Wiley-Vch, 443p.

Eck CP (2000) Effects of moisture content in solid waste landfills. Master's Thesis (Engineering and Environmental Management), Air Force Institute of Technology, Wright-Patterson Air Force Base, $103 f$.

El-Mashad HM, Zhang R (2010) Biogas production from co-digestion of dairy manure and food waste. Bioresource Technology, 101:40214028.

Esposito G, Frunzo L, Giordano A, Liotta F, Panico A, Pirozzi F (2012) Anaerobic co-digestion of organic wastes. Rev. Environmental Science Biotechnology, 11:325-341.

Gunaseelan VN (2004) Biochemical methane potential of fruits and vegetables solid waste feedstocks. Biomass and Bioenergy, 26:389-399.

Kunz A, Oliveira PAV (2006) Aproveitamento de dejetos de animais para geração de biogás. Revista de Política Agrícola, 15:28-35.

Labatut RA, Angenent LT, Scott NR (2011) Biochemical methane potential and biodegradability of complex organic substrates. Bioresource Technology, 102:2255-2264.

Lastella G, Testa C, Cornacchia G, Notornicola M, Voltasio F, Sharma VK (2002) Anaerobic digestion of semi-solid organic waste: biogas production and its purification. Energy Conversion and Management, 43:63-75.

Maciel FJ, Jucá JFT (2011) Evaluation of landfill gas production and emissions in a MSW large-scale experimental cell in Brazil. Waste Management, 31:966-977.

Mackie RI (2002) Mutualistic Fermentative Digestion in the Gastrointestinal Tract: Diversity and Evolution. Integrative and Comparative Biology, 42:319-326.

Mata-Alvarez J, Macé S, Llabres P (2000) Anaerobic digestion of organic solid wastes. An overview of research achievements and perspectives. Bioresource Technology, 74:3-16.

Mata-Alvarez J, Dosta J, Romero-Güiza MS, Fonoll X, Peces M, Astals $S$ (2014) A critical review on anaerobic co-digestion achievements between 2010 and 2013. Renewable and Sustainable Energy Reviews, 36:412-427.

Mshandete A, Kivaisi A, Rubindamayugi M, Mattiasson B (2004) Anaerobic batch co-digestion of sisal pulp and fish wastes. Bioresource Technology, 95:19-24.
O'Leary PR, Tchobanoglous G (2002) Landfilling. In: Tchobanoglous G, Kreith F. Handbook of solid waste management. 2.ed. New York Mcgraw-hill, Chap. 14, p.1-93.

Oliveira LRG, Santos Filho DA, Vasconcelos KC, Lucena TV, Jucá JFT, Santos AFMS (2018) Methanization potential of anaerobic biodigestion of solid food waste. Revista Brasileira de Engenharia Agrícola e Ambiental, 22:69-73.

Orrico Jr. MAP, Orrico ACA, Lucas Jr J (2011) Produção animal e o meio ambiente: uma comparação entre potencial de emissão de metano dos dejetos e a quantidade de alimento produzido. Revista Engenharia Agrícola, 31:399-410.

Owen WF, Stuckey DC, Healy JB, Young LY, McCarty PL (1979) Biossay for monitoring biochemical methane potential and anaerobic toxicity. Water Research, 13:485-492.

Parawira W, Murto M, Zvauya R, Mattiasson B (2004) Anaerobic batch digestion of solid potato waste alone and in combination with sugar beet leaves. Renewable Energy, 29:1811-1823.

Pearse LF, Hettiaratchi JP, Kumar S (2018) Towards developing a representative biochemical methane potential (BMP) assay for landfilled municipal solid waste - A review. Bioresource Technology, 254:312-324.

Rasi S, Läntelä J, Rintala J (2011) Trace compounds affecting biogas energy utilisation - a review. Energy Conversion and Management, 52:3369-3375.

Rincón B, Bujalance L, Fermoso FG, Martín A, Borja R (2013) Biochemical methane potential of two-phase olive mill solid waste: Influence of thermal pretreatment on the process kinetics. Bioresource Technology, 140:249-255.

Scarlat N, Dallemand J-F, Fahl F (2018) Biogas: Developments and perspectives in Europe. Renewable Energy, 129:457-472.

Schirmer WN, Jucá JFT, Schuler ARP, Holanda S, Jesus LL (2014) Methane production in anaerobic digestion of organic waste from Recife (Brazil) Landfill: evaluation in refuse of different ages. Brazilian Journal of Chemical Engineering, 31:373-384.

Schirmer WN, Gauer MA, Tomaz E, Rodrigues PRP, Souza SNM, Chaves LI, Villetti L, Olanyk LZ, Cabral AR (2016) Power generation and gaseous emissions performance of an internal combustion engine fed with blends of soybean and beef tallow biodiesel. Environmental Technology, 37:1480-1489.

USEPA-USEnvironmentalProtectionAgency(1991)EPA-450/3-90-011a Air emissions from municipal solid waste landfills - Background information for proposed standards and guidelines. $543 p$

Van Foreest F. (2012) Perspectives for biogas in Europe. The Oxford Institute for Energy Studies. Available at <https://www.oxfordenergy. org/wpcms/wp-content/uploads/2012/ 12/NG-70.pdf> Accessed: 03 Jan 2020

Vandevivere P, De Baere L, Verstraete W (2002) Types of anaerobic digesters for solid wastes. In: Mata-Alvarez J. Biomethanization of the organic fraction of municipal solid wastes. Londres, IWA Publishing, Chap. 4, p.111-140.

Ward AJ, Hobbs PJ, Holliman PJ, Jones DL (2008) Optimisation of the anaerobic digestion of agricultural resources. Bioresource Technology, 99:7928-7940

WEC - World Energy Council (2013) World Energy Resources - 2013 Survey. London, $468 p$.

WHO - International Reference Centre for Wastes Disposal (1978), CH 8600. Methods of Analysis of Sewage Sludge, Solid Wastes and Compost. 49p.

Wlodarski L, Maeda EM, Fluck AC, Gilioli D (2017) Microbiota gruminal: diversidade, importância e caracterização. REDVET - Revista Electrónica de Veterinária, 18:1-20.

Yenigün O, Demirel B (2013) Ammonia inhibition in anaerobic digestion: A review. Process Biochemistry, 48:901-911. 